\title{
単層ラチスドームの形状初期不整の推定手法について ON A METHOD FOR ESTIMATION OF AN INITIAL GEOMETRICAL IMPERFECTION IN SINGLE LAYER LATTICED DOME
}

\author{
加藤 史 郎*, 武藤 至** \\ Shiro KATO and Itaru MUTOH
}

\begin{abstract}
Initial imperfections caused by random member length errors are discussed to investigate how the impferfections appear over an entire surface of a single-layer latticed dome and what magnitude of forces is induced in constituent members. The method to evaluate the imperfections is based both on a matrix analysis and a Monte Carlo technique taken into account of some degree of joint looseness. The present procedure and the results from the numerical analysis will provide practical and effective informations when designers face to estimating the quantities of imperfections in a latticed dome at a design stage.
\end{abstract}

Keywords : single-layer latticed dome, initial geometrical imperfection, random member length error, joint looseness

単層ラチスドーム，形状初期不整，ランダム部材長さ誤差，接合部緩み

\section{1. 序}

実際の構造物に発生する初期不整に関する設計用の資 料の蓄積は，初期不整の実測データそのものの不足およ び不整要因の不確定さや発生メカニズムの複雑さ等によ り，十分と言えない。また，実測結果が手に入っても， 少ないデー夕から初期不整の持つ統計的特性を抽出して 対象となる構造物に関連する設計公式にその特性を反映 させることも現時点では困難である。

既往の研究では, 初期不整形状を先見的に, 確定論的 または確率論的に仮定しその座屈荷重や応力分布への影 響が検討されている”。また，個々の現場建て方におけ る精度管理を主眼とする調查, 研究がなされてきた。例 えば，鋼構造骨組構造物の具体的な建物について，部材 の施工精度と完了後の初期不整の測定結果がそれぞれ報 告されている ${ }^{2)-3)}$ 。組立・施工時の精度と管理を目的と して, プレファブ建築, プレキャス卜 $\mathrm{RC}$ 造と大型 $\mathrm{PC}$ パネル4および，吊（ケーブルネット）構造岛に関する 報告がある。一方吊橋, 斜張橋の初期不整や施工精度に ついて, 誤差発生の要因を構造解析に含めて精度管理に 基づく分析がなされている6!。一連の実測結果は, 極め て有益な情報源となっているものの, 構造物に生じる初 期不整を構造形式に応じて定量的に推定できるようには 論理的な検討や分析が十分なされているとはいいがた
い。このような現状から判断して, 個々の不整要因と構 造特性の具体的な関連性を検討するには，ランダムな不 規則量と考えられる初期不整による構造全体の挙動への 影響を確率・統計的に論じる必要があろう。

本論では, 内部に柱のない大規模構造物の構造形式の 一つとして，単層ラチスドームを取り上げる。このよう な構造では，互いに対等な部材がすべて組み上げられて 初めて一つの架構が形成される7”。各部材は対等の精度 で全体の構成に参加する必要があり, 部材の寸法誤差は 互いに影響し合うことになる。また，接合部の緩み（ガ 夕）も構造全体の変形に与える影響は, ビの位置につい ても対等である。接合部の形式としては種々のものが考 えられるが，組立および施工の容易さからボールジョイ ントと軸力ボルトの組み合わせによるねじ込み接合が多 く使用されている。

こうした構造架構からなる構造物の挙動に影響を与え る諸要素は種々あるが, 大規模単層ラチスドームの設計 には，座屈荷重の検討が必要であり，座屈荷重には形状 初期不整の影響が大きいといわれている8)。そこで，本 論は,構造形式に応じた初期不整敏感性を把握するには, 初期不整そのものの発生および推定が問題であると考 え，そのための解析手法について検討する。ところで, 形状初期不整は，種々の要因によって発生すると考えら
* 豊橋技術科学大学建設工学系 教授. 工博

** 岐阜工業高等専門学校建築学科 講師
Prot., Dept. of Regional Planning Toyohashi Univ. of Technology, Dr. Eng.

Lecturer, Dept. of Architecture Gifu National College of Technology 
れる。例えば，部材製作時には元たわみ，長さ誤差が， また架構の組立施工時には接合部の初期回転, 偏心と支 持構造の施工誤差などが考えられる。各々の要因は，相 互にかかわり合いながら建て方方法などにしたがって， 初期不整に対して複雑に影響を及ぼすと考えられる。

しかしながら，実大規模のラチスドームについて個々 の不整要因と発生初期不整量との関係を数値解析により 合理的に把握することも重要と判断される。筆者らは, 先に比較的簡単な解析モデルに基づきドームを構成する 部材の長さ誤差のみによって発生する初期不整の基本的 な性状について報告した"9)。本論では, 初期不整の発生 要因・誤差等を上述のねじ込み接合された構造架構につ いて概説し，誤差のモデル化の考え方と統計的に発生さ せる方法を示す。そして, 特定の形状, 境界条件のもと, ほぼ正三角形網目状からなるかなり偏平なラチスドーム について自己釣合系で数值解析する。得られた結果から， 部材長さ誤差の影響を単層ラチスドームの構造特性に関 係すると考えられる各部材および節点の位置関係ごとに 統計量の変動を分析し，初期不整を推定する。

\section{2. 初期不整の発生要因と誤差のモデル化}

序で述べた単層ラチスドームについて，基本的な初期 不整の発生のメカニズムに関係すると思われる要因を概 略的に説明してみる。ボールジョイントによるねじ込み 接合による架構では，ボール部とボルトネジとの接触の 程度が問題となる。接合部に緩みがある場合には, 使用 する接合部ごとに実験からその力学特性を明らかにし楥 みや部材の剛性をあらかじめ評価しておく必要があろ う。

このような架構では, 個々の部材, ボルトおよびボー ルジョイントが製作される際に各々の加工誤差が生じる であろう。すなわち，例えば，Fig. 1(a) に示される部 材長さ (寸法) $l$ の誤差 $\Delta l$ とジョイントの接合角度 $\theta_{1}, \theta_{2}$ の誤差 $\Delta \theta_{1}, \Delta \theta_{2}$ が問題となる。また, 架構を形成

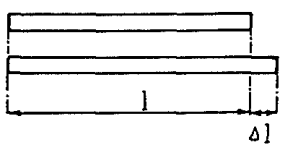

member length error $\Delta \ell$

(a)

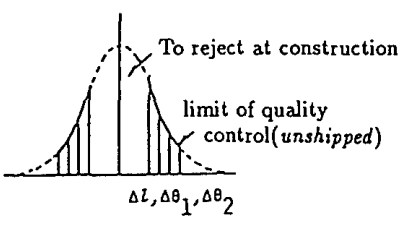

construction management

(b)

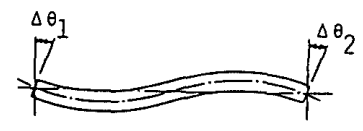

attachment angle errors $\Delta \theta_{1} \Delta \theta_{2}$

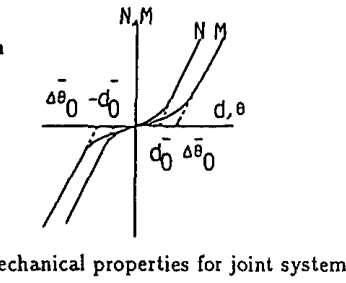

(c)

Fig. 1 Schematic illustrations for errors of member manufacture and some kinds of member assemblage

する際に, 組立時の偏心接合誤差，および建て方方法之 順序により生じる累積誤差等が問題となる。一方, 架棈 支持部の施工時には，基礎の形状と位置の誤差，アン カー・フレームの芯ずれとシューの芯ずれ等による誤差 が問題となるものの, 下部支持構造と上部架構の精度に は大きな差が生じることから，施工謰画時に適切な対応 が必要と考えられる。

また種々の構造形式および施工方法などを想定した上 で設計時にあらかじめ考慮されるべき問題として， Fig. 1(b) の頻度分布で示されるような管理限羿内で架 構の組立てにあたり部材の製作誤差を接合部の緩みで吸 収可能な範囲で除去する場合, あるいは Fig. 1(c) に示 されるような紱みを許容し組み上げる Fig.1(b) の破線 の頻度分布の場合が考えられる。

本論では, 後者の考え方により接合部の緩みを考慮し， 部材長さ誤差のみを取り上げる。その誤差は, 部材製作 時に品質管理がなされ十分その管理限界内でおうめられ ると仮定する。部材寸法に関する品質管理では, 寸法の 補正・調整の方法として, 長すぎれば切断し短いと作り 替える等が考えられる。したがって，部材長さ誤差の決 デル化にあたっては，基本となる一定の平均部材長に対 し平均值ゼロおよび, 加工精度と管理限界を考愿して設 定した標準偏差で打ち切りされる正規分布に従う不規則 変量を仮定した。

\section{3. 解析モデルと解析方法}

\section{3-1 構造概要}

単層ラチスドームの挙動に影響する諸量には, 構造物 の規模, 全体形状および, 境界条件なよ゙があげられる。 本研究で解析するばね接合単層ラチスドームの非態に関 し，Fig.2(a) に全体形状と境界条件が，Fig.2(b) に 単位ドームと部材半開角 $\phi_{1}$ が示される。すなわち, 正 6 角形平面状の球形ドームである。ドームの各節点は, 曲率半径 $R$ の球面上にありドームの頂点と一組の最外 周の各隅点とを結ぶ稜線についてドーム開角 $2 \psi_{0}$ をス パン数で等分して円弧上の座標が定められる。また,ドー ムの周方向の各節点は, 各々が描く円弧を等分割して各 座標が求められている。このようにして, 各部材の長さ はほぼ等しくなるように完全形状のドームを分制されて いるものの, 各々の長さはわずかながら異なっている。 本解析では, 曲率半径 $R=40.12 \mathrm{~m}$, ドーム開角 $2 \psi_{0}=$ $20^{\circ}$ ，スパン数 4 の場合を扱っている。

部材半開角について, 既往の研究では $1.5^{\circ}$ から $7^{\circ}$ 程 度が多くみられるが，特に浅いライズのラチスドーム111 を前提亡し， $\phi_{1}=2.5^{\circ}$ の一ケースだけ想定した。境界 条件は, 外周上の隅点 (黒丸) では, $X, Y, Z$ 方向の 変位が生じないように拘束され, 他の外周上の節点（白 丸）は， $Z$ 方向の変位を生じないように拘束され， $X$ ， 


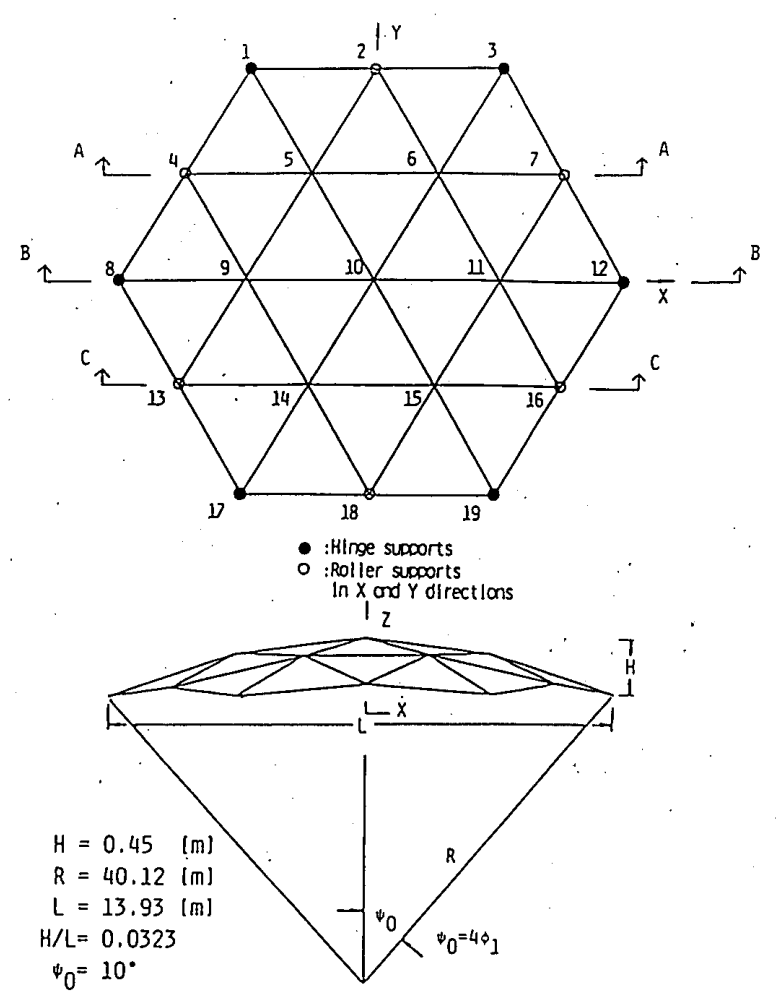

(a)

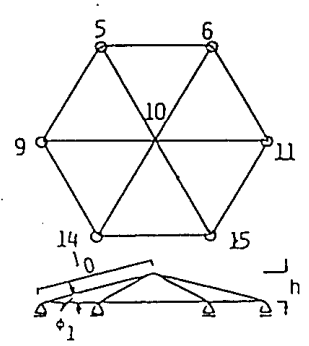

(b)

Fig. 2 Configuration of a latticed dome (a) geometry of four-spanned hexagonal single-layer dome, (b) unit hexagonal dome at apex and member half open angle $\phi_{1}$

$Y$ 方向は，ローラー支持されているものとした。

\section{3-2 部材モデル}

解析に用いた部材モデルと力学特性（緩みを考慮する 場合）が，Fig.3(a) に示される。軸力特性は，Fig. 3(b) に示すように，ボールジョイントの緩みを考慮して初期 戌性を $\gamma_{a}=1 / 10$ に低娍して緩みを $\bar{d}_{0}= \pm 0.05 \mathrm{~cm}$ とし た。曲げばね特性は, Fig. 3(c) に示すように, 初期剛 性を $\gamma_{B}=1 / 10$ に低減し緩みを $\overline{\Delta \theta}_{0}= \pm 0.001 \mathrm{rad}$. とし た。解析に用いた部材の断面性能等は, Table 1 にまと めて示される。

\section{3-3 基本式および解析方法}

Fig. 4 に示す座標系にある部材モデルに基づき，通常 のマトリックス法に従い定式化を行った。その際以下の 各項目を考慮した。すなわち，a）ランダムな部材長さ 誤差，b）軸力特性の緩み，c）ばね要素の回転特性の 緩み，そしてd）偏心接合，の4 項目である。

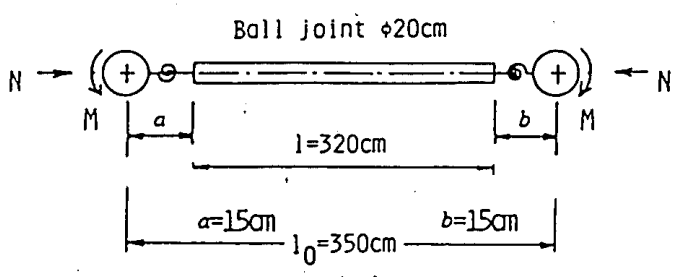

(a)

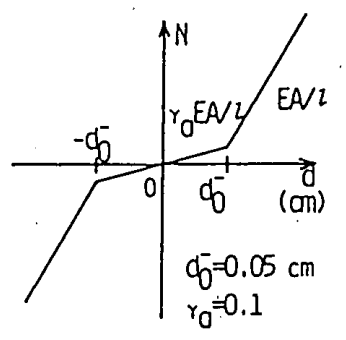

(b)

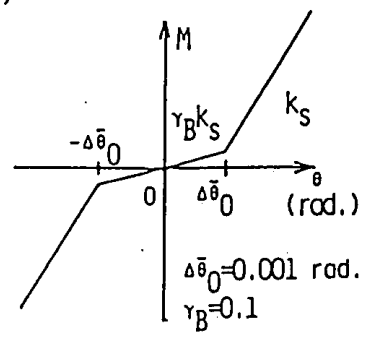

(c)
Fig. 3 Analytical model of constituent member unit and its mechanical properties with consideration of joint loosenesses (a) beam element with nondimensional rotational springs and rigid balls at both ends (b) axial force-deformation relationships (c) moment-rotation relationships

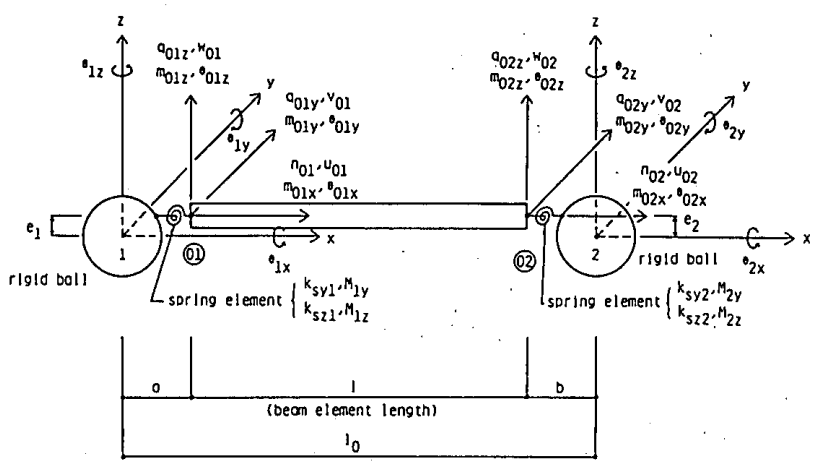

$0, b: f$ Intce slze of rigid body; $e_{1}, e_{2}$ :eccentricity lensth

Fig. 4 Coordinate systems of member consisted of beam element, nondimensional springs and finite-sized rigid spherical balls at both member ends

Table 1 Properties of constituent member unit

\begin{tabular}{|lccccc|}
\hline \multicolumn{1}{|c}{ PROPERTIES } & \multicolumn{2}{c}{ PIPE } & \multicolumn{2}{c|}{ CONNECTOR } \\
\hline Diameter & $\phi$ & 16.5 & $\mathrm{~cm}$ & 3.6 & $\mathrm{~cm}$ \\
Thickness & $\mathrm{t}$ & 0.45 & $\mathrm{~cm}$ & - & \\
Member's length & $\mathrm{L}$ & 320.0 & $\mathrm{~cm}$ & 5.0 & $\mathrm{~cm}$ \\
Cross-section oreo A & 22.72 & $\mathrm{~cm}^{2}$ & 10.18 & $\mathrm{~cm}^{2}$ \\
Moment of inertio & 1 & 733.94 & $\mathrm{~cm}^{4}$ & 8.24 & $\mathrm{~cm}^{4}$ \\
Section modulus & $Z$ & 88.85 & $\mathrm{~cm}^{3}$ & 4.58 & $\mathrm{~cm}^{3}$ \\
Young's modulus & E & $2.1 \times 10^{6}$ & $\mathrm{~kg} / \mathrm{cm}^{2}$ & $2.1 \times 10^{6}$ & $\mathrm{~kg} / \mathrm{cm}^{2}$ \\
Spring constont & $\mathrm{ks}$ & $4.82 \times 10^{6}$ & $\mathrm{~kg} \cdot \mathrm{cm}$ & $3.46 \times 10^{6}$ & $\mathrm{~kg} \cdot \mathrm{cm}^{2}$ \\
\hline
\end{tabular}

部材 01-02 の基本式：部材の力学特性は, 通常のはり要 素亡同様に考える。しかし, 部材長さ誤差と軸力特性の 緩みを考慮して, 力学特性が以下のように修正される。 節点 01,02 の軸方向変位 $u_{01}, u_{02}$ による部材の伸びを $\xi と し て, F i g .3(b)$ を参照し軸力 $n$ を発生させる規準 ひずみ $d$ は, 部材長さ誤差 $\Delta l$ と等価な伸びなら軸力が 発生しないと考え $d=\xi-\Delta l$ と定義される。したがっ 
て, 部材の軸力特性は次式で表現できる。

$$
\begin{gathered}
n=\gamma_{a} \times \frac{E A}{l} \times d ; \bar{d}_{0} \geq d \geq-\bar{d}_{0} \cdots \cdots \cdots \cdots \cdots \\
n=\frac{E A}{l} \times\left(d-\bar{d}_{0}\right)+\gamma_{a} \times \frac{E A}{l} \times \bar{d}_{0} ; d>\bar{d}_{0} \\
\cdots \cdots \cdots \cdots \cdots \cdots \cdots \cdots \cdots \cdots \cdots . . . \cdots \cdots \cdots \cdots \cdots \cdots \cdots \\
n=\frac{E A}{l} \times\left(d-\bar{d}_{0}\right)-\gamma_{a} \times \frac{E A}{l} \times \bar{d}_{0} ; d<-\bar{d}_{0}
\end{gathered}
$$

以上を考虑して, 部材の基本式が下式のようにマト リックス表現される。

$$
\left\{f_{0}\right\}=\left[k_{0}\right]\left\{d_{0}\right\}-\left\{\bar{f}_{0} \mid \cdots\right.
$$

ここで, Fig. 4 を参照して部材の両端の作用力 $\left\{f_{0}\right\}$ と 変位 $\left\{d_{0}\right\}$ を次の記号で表示する。

$$
\begin{aligned}
& \left|f_{0}\right|=\mid \begin{array}{llllll}
n_{01} & q_{01 y} & q_{01 z} & m_{01 x} & m_{01 y} & m_{01 z}
\end{array} \\
& \begin{array}{llllll}
n_{02} & q_{02 y} & q_{02 z} & m_{02 x} & m_{02 y} & \left.m_{02 z}\right|^{T}
\end{array} \\
& \left\{d_{0}\right\}=\left\{\begin{array}{llllll}
u_{01} & v_{01} & w_{01} & \theta_{01 x} & \theta_{01 y} & \theta_{01 z}
\end{array}\right. \\
& \begin{array}{llllll}
u_{02} & v_{02} & w_{02} & \theta_{02 x} & \theta_{02 y} & \left.\theta_{02 z}\right]^{T}
\end{array}
\end{aligned}
$$

$\left\{\bar{f}_{0}\right\}$ は, 部材の長さ誤差 $\Delta l$ により発生する等価部材内 カベクトルであり，楥み量と規準ひずみの関係に応じて 要素 $\bar{f}_{0}(1), \bar{f}_{0}(7)$ に対して次式のように表され，それ以 外の要素はゼロである。

$$
\begin{aligned}
& \bar{f}_{0}(1)=-\gamma_{a} \frac{E A}{l} \Delta l=-\bar{f}_{0}(7) \\
& \bar{d}_{0} \geq d \geq-\bar{d}_{0} \\
& \bar{f}_{0}(1)=-\left[\frac{E A}{l}\left(\Delta l+\bar{d}_{0}\right)-\gamma_{a} \frac{E A}{l} \bar{d}_{0}\right]=-\bar{f}_{0}(7) \\
& d \geq \bar{d}_{0} \\
& \bar{f}_{0}(1)=-\left[\frac{E A}{l}\left(\Delta l-\bar{d}_{0}\right)+\gamma_{a} \frac{E A}{l} \bar{d}_{0}\right]=-\bar{f}_{0}(7) \\
& d \leq-\bar{d}_{0}
\end{aligned}
$$

また, $\left[k_{0}\right]$ は，緩み量が $|d| \geq \bar{d}_{0}$ の範囲なら通常の部 材剛性マトリックス（大きさ $12 \times 12 ）$ であるが, $\bar{d}_{0} \geq$ $d \geq-\bar{d}_{0}$ では, 初期剛性の低減を考慮して下式のよう に与えられる。

$$
\left.\begin{array}{l}
k_{0}(1,1)=\gamma_{a} \frac{E A}{l}=k_{0}(7,7) \\
k_{0}(7,1)=-\gamma_{a} \frac{E A}{l}=k_{0}(1,7)
\end{array}\right\}
$$

01，02 端の曲げばねの基本式：部材の両端のばねは, Fig. 4 に示す $y$ 軸, $z$ 軸回りの回転に抵抗し, 各々独立 とする。同様に，曲げばねの緩みを考慮して，例えば 01 端の $y$ 軸回りの曲げ特性は, 以下の上うに示される。

$$
\begin{gathered}
M_{1 y}=k_{s y 1} \times\left(\theta_{1 y}-\theta_{01 y}\right) \times \gamma_{B y 1} \cdots \cdots \cdots \cdots \cdots \cdots \cdots(9) \\
\quad\left|\theta_{1 y}-\theta_{01 y}\right| \leq \Delta \bar{\theta}_{01 y} \\
M_{1 y}=k_{s y 1} \times\left(\theta_{1 y}-\theta_{01 y}-\Delta \bar{\theta}_{01 y}\right)+\gamma_{B y 1} \times k_{s y 1} \times \Delta \bar{\theta}_{01 y}
\end{gathered}
$$

$$
\begin{aligned}
& \left(\theta_{1 y}-\theta_{01 y}\right) \geq \Delta \bar{\theta}_{01 y} \\
& M_{1 y}=k_{s y 1} \times\left(\theta_{1 y}-\theta_{01 y}+\Delta \bar{\theta}_{01 y}\right)-\gamma_{B y 1} \times k_{s y 1} \times \Delta \bar{\theta}_{01 y} \\
& \left(\theta_{1 y}-\theta_{01 y}\right) \leq-\Delta \bar{\theta}_{0 y 1}
\end{aligned}
$$

同様に, $z$ 軸, そして 02 端の $y, z$ 軸回りに対して も求められる。上述した曲げば称牲を考慮して, 部材 端変位と節点 1,2 (Fig. 4 の用体部分について) に関す るモーメントの釣合いが，下式のマトリックス表示によ り与えられる。

$$
\left\{s_{0}\right\}=[A]\left\{d_{1}\right\}+[B]\left\{\theta_{0}\right\}-\left\{s_{0}\right\}
$$

ここで, $\left|s_{0}\right|$ は，曲げばねにより発生するモーメントで ありその要素には, $M_{1 y}, M_{1 z}, M_{2 y}, M_{2 z}$ を含み, $\left\{d_{1}\right\}$ は, 節点 1,2 の変位ベクトルであり，

$$
\left\{d_{1}\right\}=\left\{\begin{array}{lllllllll}
u_{1} & v_{1} & w_{1} & \theta_{1 x} & \theta_{1 y} & \theta_{1 z} & \theta_{2 x} & \theta_{2 y} & \theta_{2 z}
\end{array}\right]^{T}
$$

また $\left\{\theta_{0}\right\}$ は，部材要素の回転べクトルで $\left\{\theta_{01 y} \theta_{01 z} \theta_{02 y}\right.$ $\left.\theta_{022}\right]^{T}$ に対応する。 $[A],[B]$ は，上述した緩み特性から 求められる曲げばねの回転剛性を表す。一方先述した部 材端変位ベクトル $\left\{d_{0} \mid\right.$ は, 接合部の剛域長さ $a, b$ と鉛 直方向の偏心 $e_{1}, e_{2}$ とを考慮して，次式で表される。

$$
\left\{d_{0}\right\}=[R]\left\{d_{1}\right\}+\left[R_{\theta}\right]\left\{\theta_{0}\right\} \text {. }
$$

ただし， $[R]$ は節点変位に関係する係数マトリックス, $\left[R_{\theta}\right]$ は部材両端部での回転成分であるが, 本論では詳 細は省いている。なお, $\left\{\widehat{S}_{0}\right\}$ は, 節点と部材端での回耺 量の差に対する曲げばねの緩みにより発生する付加モメトである。以上より, 式 (13) の $\left|\theta_{0}\right|$ 項を式 (12) に 代入して, 等価材への置換により単材としての基本式が 誘導できる。

解析方法: 数值計算は, 一般のマトリックス法之変わら ない。なお, 部材長さ誤差を含むを単層ラチスドームの 解析に当たっては, 以下の仮定を設定する。

(a) ドームを構成する各節点は, 組み立てるまでは完 全系上にある (Fig. 2(a))。

（b）部材要素は, 鋼管で直線材であり, 部材断面積は 同一とする。

(c) 接合部の緩みは, 確定量として与え力学特性は各 接合部で同一とした (Fig. 3)。その大きさは，部材の 軸特性に関係する $\bar{d}_{0}$ と曲代特性に関係する $\overline{\Delta \theta}_{0}$ であ り, それぞれ部材長さあるいは部材半開角に比べて十分 小さい。

（d）接合部は，部材とばねとパネル（剛体）からなる モデル ${ }^{12}$ とし(Fig.4)，ばねの長さは無視する。また， 接合部の偏心 $e_{1}, e_{2}$ は無いものとする。

解析に用いた接合部の緩みとして以下の 4 種類を想定 した。全く緩みがない場合 (case 1), 軸力特性のみに 緩みを考慮する場合（case 2), 曲げば称の回転特性の み緩みを考慮する場合（case 3) そして，両者に緩みを 考慮する場合 (case 4) である。各々の場合について, ランダムな部材長さ誤差の標準偏差 $\sigma_{T G}$ ごとに，100サ 
ンプルずつに対して，無荷重状態で数值計算を行った。 ただし，緩みを考虑する場合には，部材長さ誤差を一度 に与えるのではなく分割して解析を進めて繰り返し計算 によって真の変位に収束させている。

\section{4. 部材長さ誤差の発生方法}

部材長さ誤差は，鉄骨精度测定指針 ${ }^{10}$ によると，指定 寸法に対する標準許容差の表現で, 長さ $10 \mathrm{~m}$ までの柱 およびはりについて $(-3 \mathrm{~mm},+3 \mathrm{~mm})$ とされている。 本論では, 部材長が約 $300 \mathrm{~cm}$ 程度のものを想定し, 品質管理の精度限界として $\pm 0.10 \mathrm{~cm}, \pm 0.05 \mathrm{~cm}$, $\pm 0.025 \mathrm{~cm}$ ，そして $00.0125 \mathrm{~cm}$ の 4 種類を設定した。 これらの值は, それぞれ標準許容差の $1 / 3,1 / 6,1 / 12$, $1 / 24$ 倍に対応する。こうして, 設定した部材長さの精 度限界を誤差発生のための設定標準偏差 $\sigma_{T G}$ として採用 する。設定された部材長さ誤差の標準偏差の各值 $\sigma_{T G}=$ $0.0125 ， 0.0250,0.0500,0.1000 \mathrm{~cm}$ を用い平均值ゼロ とし, Box-Muller 法で各々に対し 1000 個づつ擬似正 規乱数を発生させる。作成した母集団に対して， $\pm 2 \sigma_{T C}$ (設定標準偏差の 2 倍) で分布の両裙をカットオフし, 所要部材数だけ部材誤差の標本をランダムに抽出して, 各々 100 ケースずつ発生させた。なお予備計算では, 乱 数発生のシードの違いの検討と誤差発生の頻度分布の比 較のため 2 種類のシードについて 300 個のサンプル群を 用いた。各シードについて具体例をAppendix に示すが, サンプル群と抽出群とはほぼ類似の分布を示すという結 果を得ている。

\section{5. 初期不整の統計的分析と推定方法}

部材長さ誤差 $\Delta l$ を有する各部材で構成される単層う チスドームに対して, 数值解析を行って求まる初期不整 および, 部材伸びと発生軸力について統計的に分析する。 得られる初期不整, すなわち初期変位には, 水平方向成 分亡鉛直方向成分がある。本論では, 推定する初期不整 として鉛直変位成分を対象とする。

初期不整を統計的に分析し推定するために, 以下に示 す視点を設定した。

1）解析に用いた部材長さ誤差 $\Delta l$ の標準偏差 $\sigma_{\Delta l}$ と, 数值計算から求まる鉛直変位 $D$ と次式で定義する鉛直 相対変位 $\Delta W$ の各々の平均值 $\operatorname{mean}(D), \operatorname{mean}(\Delta W)$ と標準偏差 $\sigma_{D}, \sigma_{\Delta W}$ の分布との関係を調べる。

$$
\Delta W(i)=D(i)-\frac{1}{n} \sum_{j=1}^{n} D(j)
$$

ここで, 鉛直変位 $D$ は, 個々の節点に関する鉛直方向 の変位量であり; 鉛直相対変位 $\Delta W$ はある節点 $i$ を中 央に持つ 1 パネル単位についてその節点の絶対鉛直変位 $D(i)$ から，隣接する節点 $j(n$ 個）に対し求めた $D(j)$ の平均を差し引いた值である。このような式を用い相対
鉛直変位を求めるのは, おもに次の理由による。序でも 触れたように，比較的偏平な単層ラチスドームでは，局 部座屈が生じやすく, その座屈範国の基本となるスケー ルは 1 パネル単位と考えられる。そこで, 座屈挙動に影 響すると思われる初期不整の分布を分析するための視点 として上式を用いることにした。

同様にして, 部材伸び $\xi$ と発生軸力（以下， $A F$ と 略記する) の各々の平均值と標準偏差 $\sigma_{\xi}, \sigma_{f}$ の分布に ついても分析する。

2）先述した接合部のモデルとして考虑される緩みの初 期不整分布に対する影響を調べる。その際, 構造全体と しての基本統計量（ここでは，平均值，標準偏差および 分布をいう）の分析と先述した1パネル単位ごとの相対 的な基本統計量の分析を併せて行う。さらに, 部材長さ 誤差のばらつきの程度と対応する初期不整などのばらつ きを標準偏差の平均と標準偏差により把握する。こうし た方法に基づく意味は, 初期不整の空間分布をドームの 構造特性との関連で分析するためにドームを構成する部 材および節点位置ごとに, 解析から得られた諸量の特徴 的な傾向を抽出して, 構造特性が異なることによる発生 初期不整の違いの程度を説明できるものか試みることに ある。

3）一連の分析により, 部材長さ誤差 $\Delta l$ の標準偏差 $\sigma_{\Delta l}$ に関する基本統計量に基づき初期不整の標準偏差の 統計量を空間分布と併せて発生初期不整のもつ統計的特 性を推定する。

\section{6. 解析結果}

各ケースごとおよび部材長さ誤差の設定標準偏差ごと に対し 100 サンプルずつ数値計算を行って得られた諸量 について先述した方法で統計的に分析した結果を述べ, 初期不整の推定およびその特性に関する特徴的な傾向が 以下にまとめられている。

\section{6-1 部材長さ誤差と部材伸びの関係}

Fig. 5 には, 部材長さ誤差 $\Delta l$ の設定標準偏差 $\sigma_{T G}$ の 各値ごとに, case 1 から case 4k対し, 計算を行って

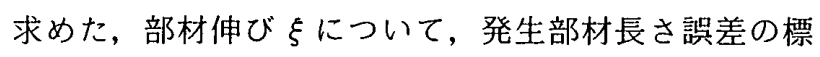
準偏差 $\sigma_{\Delta l}$ と部材伸びの標準偏差 $\sigma_{\xi}$ の統計量がまとめ られている。すなわち, 各々の標準偏差の平均値 $E\left(\sigma_{\Delta l}\right)$, $E\left(\sigma_{\xi}\right)$ 之標準偏差の標準偏差 $\sigma\left(\sigma_{\Delta l}\right), \sigma\left(\sigma_{\xi}\right)$ をプロットし てある。図中の直線は, 勾配 1.0 の場合を参考に示すも のである。

同図より全体として，両者は線形関係にあり勾配はお よそ 0.9 といえる。case 2 の場合は， $\sigma_{T G}=0.025,0.05$ $\mathrm{cm}$ をはさみ若干の非線形性がうかがわれる。これは, 軸特性にのみ䋸みを考慮していることと仮定した接合部 の初期勾配域（士0.05 cm) の特性が反映されるためと 考えられる。解析に用いた曲げばね特性による部材伸び 


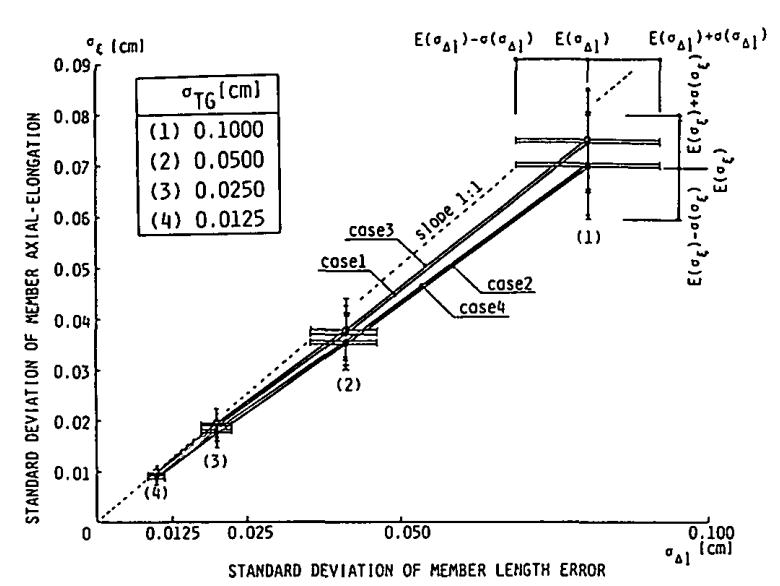

Fig. 5 Effect of member length errors on the member axial elongations in terms of statistics on standard deviations

への影響は，それぼど著しくないと考えられる。しかし ながら, 部材と接合部との取り付け角度誤差がある場合 に対する検討が望まれる。

\section{6-2 部材伸びと発生軸力の関係}

Fig. 6 には, 部材伸び $\xi$ と発生軸力 $A F$ の各々の標 準偏差 $\sigma_{\xi}, \sigma_{f}$ の統計量の関係を示す。先に述べた関係 と同様に, case 1，3の軸特性の緩みを考慮しない場合 と case 2,4 の軸特性の緩みを考慮する場合とのグルー プ化が顕著であり, case 2, 4 の場合, 非線形性がみら れる。case 1，3では, $A F$ の標準偏差 $\sigma_{f}$ の平均值 $E\left(\sigma_{f}\right)$ とその標準偏差 $\sigma\left(\sigma_{f}\right)$ もきわめて大きく, case 1 に対して case 2, 4 の場合, 発生軸力はぼぼ $1 / 6$ 程度に 減少している。case 2 と case 4 について比較すると, 発生軸力は後者の方がわずかに低い傾向にあり曲げばね

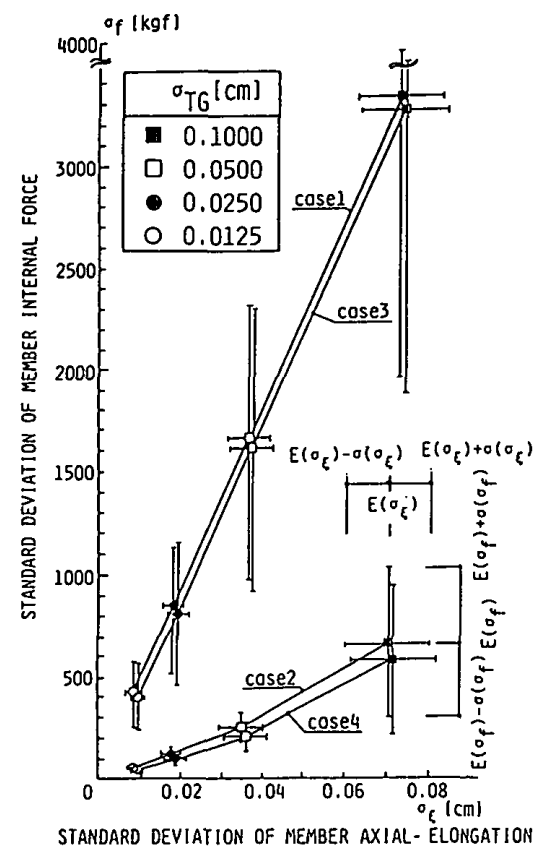

Fig. 6 Representative relations of standard deviations for member internal axial forces against member elongations
特性の緩みの影響がみられる。

6-3 部材長さ誤差と発生初期不整との関係

部材長さ誤差 $\Delta l$ の発生サンプルの標準偏差 $\sigma_{\Delta l}$ に対 する鉛直変位 $D$ と鉛直相対変位 $\Delta W$ の標準偏羓 $\sigma_{D}, \sigma_{\Delta l}$ の変動について, その両者の関係を各々 Fig. 7, Fig. 8 に示した。曲げばね特性の緩みを考慮しない case 1 と case 2 は，ほぼ線形関係にあり, case 4 の曲げばね特性 の緩みも考慮する場合には， $\sigma_{T G}=0.025,0.05 \mathrm{~cm}$ を挟 んで非線形性がうかがわれるが，以降はその勾配法 case 2 と似通っている。なお図中の破線は, 両者の関係 を概説する勾配で参考のために描かれている。

6-4 初期不整分布と発生部材軸力の関係

構造全体に関する鉛直相対変位 $\Delta W$ の標準偏差 $\sigma_{\Delta W}$ 之, 発生部材軸力 $A F$ の標準偏差 $\sigma_{f}$ の統計量の関係が Fig. 9 に示される。case 1 の場合, その勾配はほぼ $1000 ： 0.15$ で線形関係にある。他の各 case は, 若干の 非線形性がうかがわれる。

いづれの case についても仮定した接合部の力学特性 の違いが反映されているといえよう。なお，十字の付い てない各プロットは， $\sigma_{f}$ に関する鉛直変位 $D$ の標準偏 差 $\sigma_{D}$ による変動を表す。case 1 の場合, その勾配はほ ぼ $2000: 0.45$ となり，その変動は $\sigma_{f}$ に対する $\Delta W$ D

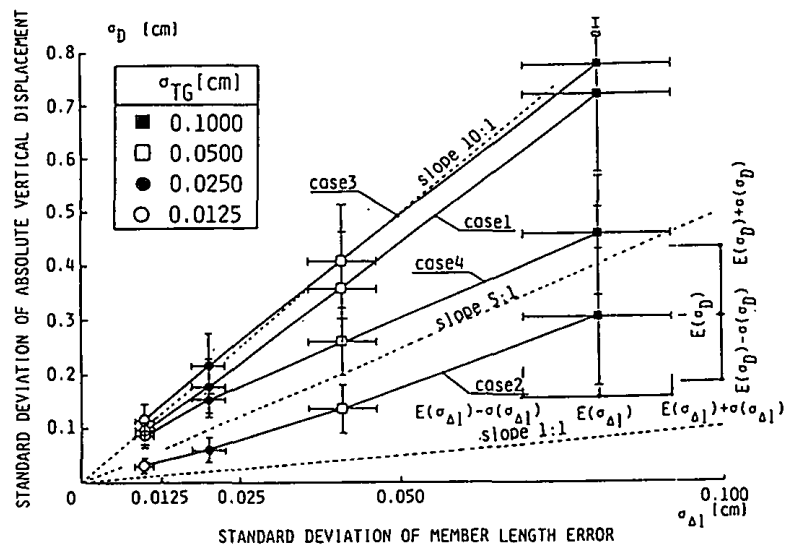

Fig. 7 Effect of member length errors on the initial vertical displacements

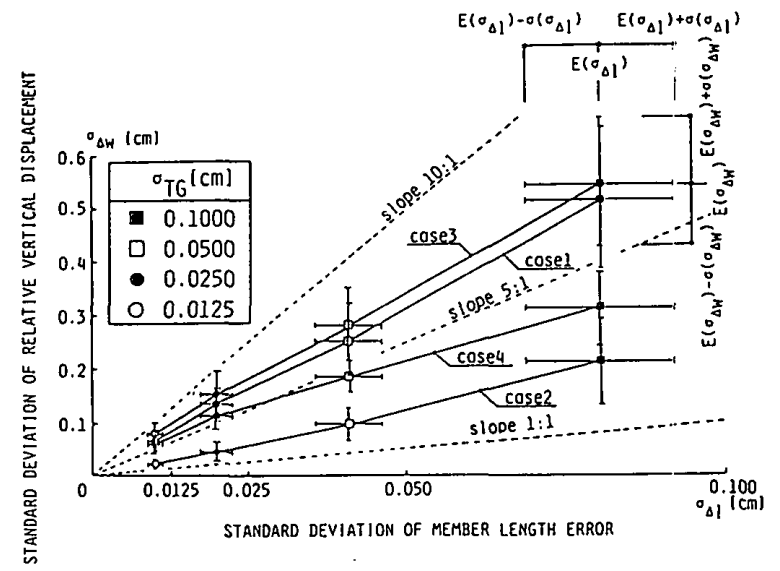

Fig. 8 Effect of member length errors on the relative initial vertical displacement 


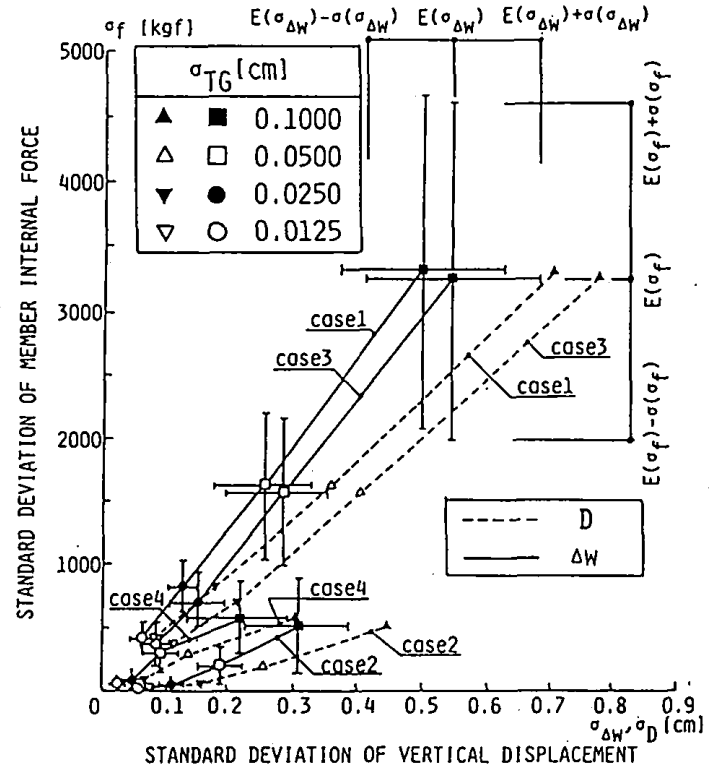

Fig. 9 Representative relationships of member internal axial force against initial geometrical imperfection in view of a root-mean-square statistics for each dome analized

勾配に比較して，約 $2 / 3(70 \%$ 程度）といえる。この ように得られた結果は，接合部のモデルに影響されるこ とから，緩み特性に関する夷際のデー夕を蓄積して，解 析に取り入れることが，重要な研究課題と考えられる。 6-5 発生初期不整の特性

以上の結果をふまえて, 次に, 発生初期不整の統計量 の特徵的な傾向について述べる。

構造全体としての初期不整の特性：各通り $(\mathrm{a}, \mathrm{b}, \mathrm{c})$ に ついて, 鉛直変位 $D$ と鉛植相対変位 $\Delta W$ のサンプル平 均を case 別に $\sigma_{T G}=0.05 \mathrm{~cm}$ の場合について, Fig. 10 に例示した。図中の mean $(D)$ に関する各直線は, case ごとの全体サンプルについて求めた $D$ の平均值を示す。 case 2, 4 では, すべての節点で mean $(D)$ は負值を示し 曲げばねに考虑した緩みの影響が現れている。

節点 $5,11,14$ は, すべての case で mean $(D)$ が負值 （鉛直下方）を示す。図中節点 $6,9,15$ も負值を示すが, その值は構造全体として求めた $D$ の全体サンプルの平 均値（図中の各直線で示される）を境にして，節点 10 も同様に，全体サンプルの平均值を 3 節点とも上回って いる。case 1，3（軸特性の緩みを考慮しない）では正值 （鉛直上方）を示す。さらに，節点 6,15 は，各々の構 造全体としての初期不整の平均值が最小となっている。 同図より節点 5,11 は，各 case ごとに同程度の変動を 示し，節点 14 はすべてのケースに対して最大の負値を 示す。同図に示す mean $(\Delta W)$ のプロットは，節点 5 , 11，14 が負值を取る傾向を顕著に表している。なお， mean $(\Delta W)$ に関し求めた全体サンプルの平均值は，す べての case・についてほぼゼロとなった。

Fig. 11 には， $\sigma_{T G}=0.05 \mathrm{~cm}$ に対し $D$ と $\Delta W$ に関す

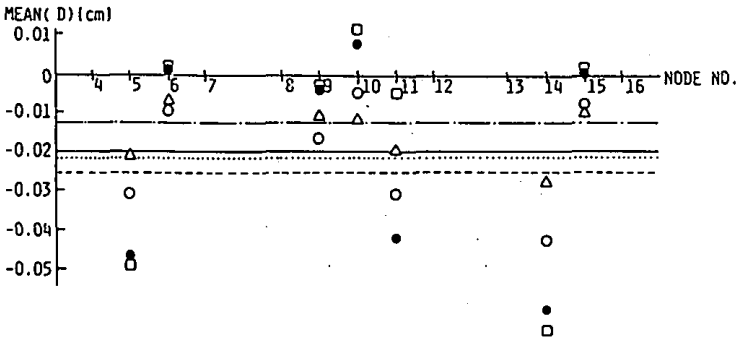

(a)
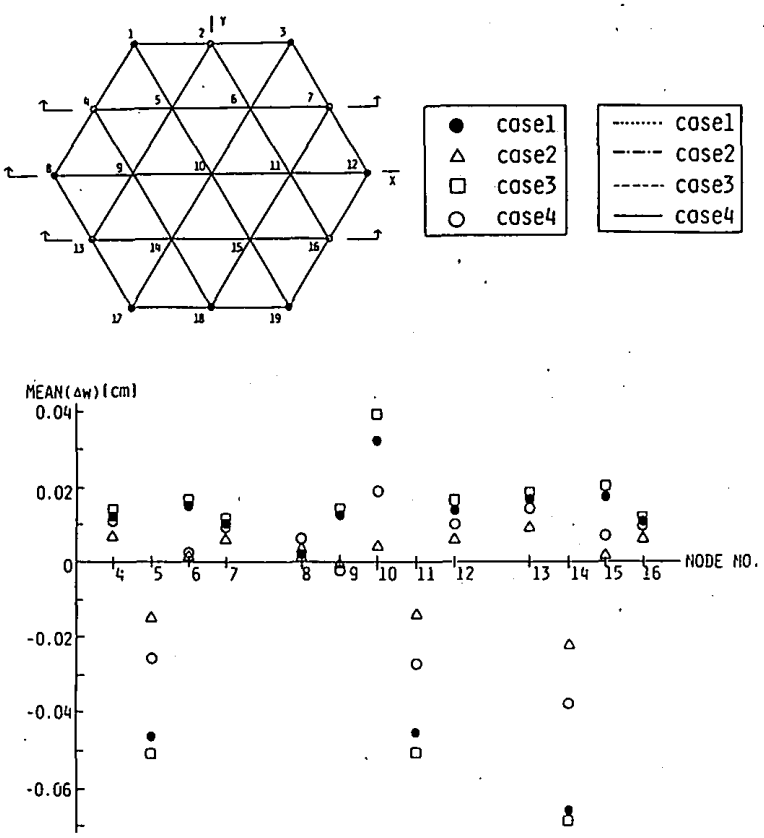

Fig. 10 Spatial distribution of $\mathrm{rms}$ mean values of initial geometrical imperfection in a hexagonal latticed dome $\left(\sigma_{T C}=0.05 \mathrm{~cm}\right)$ (a) mean values of initial vertical displacements (b) mean values of relative initial vertical displacements

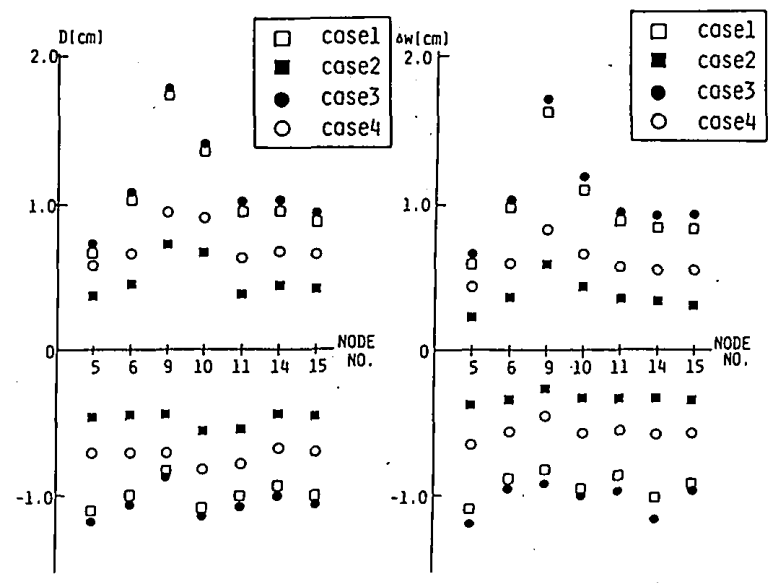

Fig. 11 Spatial distribution of min-max value of initial geometrical imperfection

る最大値と最小值を比較して例示されている。Fig. 10, Fig. 11 から, 節点 11,14 の初期不整の変動の仕方が逆 転していることがわかる。つまり，Dの平均值は，節 点 11 が 14 より小さいのに対し, 負值の最大值の変動は, 節点 14 の方が小さくなっている。一方 $\Delta W$ でみると， 


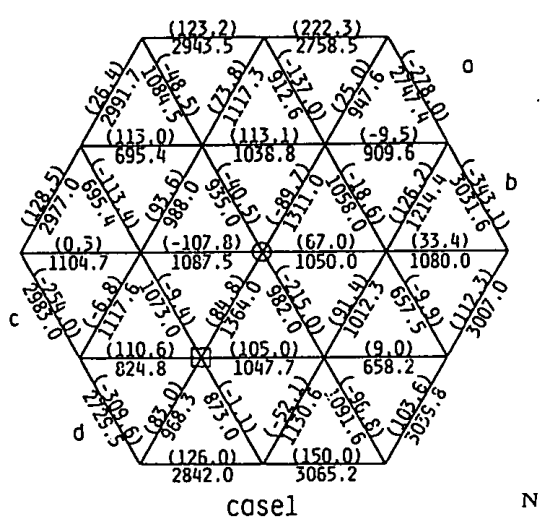

OTATION

O NODE 10

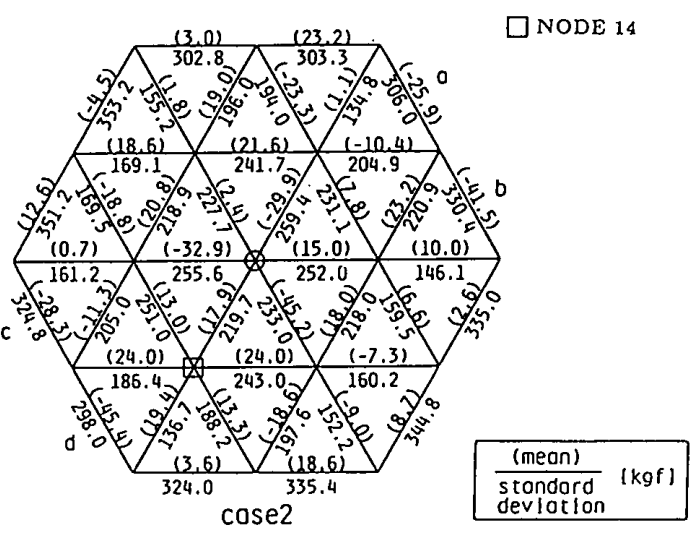

Fig. 12 Spatial distribution of means and standard deviations of member internal axial forces $\left(\sigma_{\tau c}=0.05 \mathrm{~cm}\right)$

負の最大值の変動の様子は, 雨節点の平均値の変動とに かよっている。正值の鉛直相対変位については, 節点 9 で突出し, 節点 6,10 もかなりの変動がみられる。しか しながら，すべての case について各節点間の変化の程 度は似通っている。

1 パネル単位の初期不整の特性：次に，1 パネル単位で の初期不整の特徵的傾向について着目する。Fig. 12,

Fig. 13 から支持境界周辺パネルと頂部のパネルとの相 違点，さらに，鉛直変位の負值を示すパネルの発生初期 不整の特性について考察する。

Fig. 12 に示す鉛直相対変位 $\Delta W$ と発生軸力 $A F$ 標準 偏差 $\sigma_{\Delta w}, \sigma_{f}$ の関係から，頂部のパネル（節点 $10 を 中$ 央とするの場合) の case 1 の勾配は，およそ1000： 0.4 となり，先に示したFig. 10 の全体構造に関する勾 配 $1000 ： 0.15$ に比べてかなり低下している。また，各 case 別の両者の関係のうち, case 2 と case 3 の逆転が 見られる。境界周辺のパネル（例として節点 14 を中央 とする場合）については，概して case 1 の勾配が 1000 $: 0.3$ 程度になっている。

Fig. 13 には，各パネルごとに求めた部材番号ごとの 発生軸力 $A F$ のサンプル平均と標準偏差を, 各 case と $\sigma_{T G}$ ごとに分布図としてまとめた結果のうち case 1 と case 2 について $\sigma_{T G}=0.05 \mathrm{~cm}$ に対して例示されている。
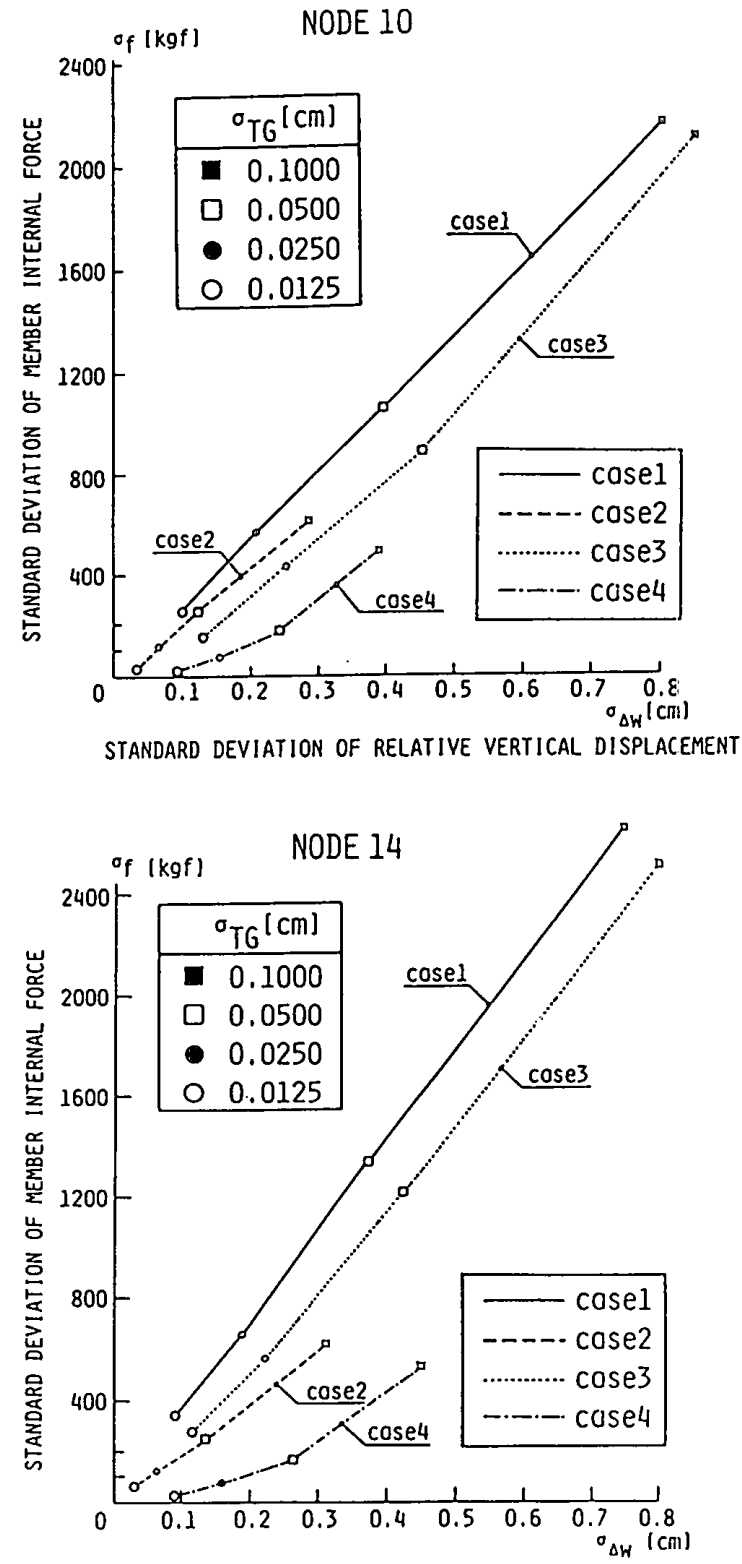

STANDARD DEVIATION OF RELATIVE VERTICAL DISPLACEMENT

Fig. 13 Representative relationships of member internal axial forces against relative initial vertical displacement for each unit hexagonal panel in terms of local average statistics

なおすべての caseについて，図中の部材 $a, b, c, d に$ 対応する発生軸力 $A F$ の平均值は負值（压縮側）となっ た。他の境界上の $A F$ は，ほとんどが正值（引張側） となっている。case 2 は， $\sigma_{T G}=0.10 \mathrm{~cm}$ を除いて，す べての $\sigma_{T C}$ で節点 $5,11,14$ につながる各々 6 本の部材 の軸力の平均値の符号が正値となっていることおよび, 節点 10 につながる 6 本の部材は，符号が交互に入れ替 わっているのが特徵的である。また，節点 10 につなが る $A F$ の標準偏差は, 総じてその変動が少ないのに対 し，支持境界の隅点の各々につながる 6 本の部材の軸力 は, 前者の 0.6 加ら 0.8 倍程度に減少している。特に， 節点 6,14 に関係する部材がその減少の度合いが著し い。case 1，3では，節点 6,9 を含むパネルに関係する 
$A F$ の平均值が負值を示す部材の数は, case 1 では 6 本 中 4 本で部材位置の出現パターンが同じ（ $\sigma_{T C}=0.025$ $\mathrm{cm}$ を除く)であり，他のパネルについてもそのパター ンは，似通る傾向にある。case 3 の場合は，節点 9 を含 むパネルの他にも部材位置の出現パターンは, case 1 に 比べてかなり異なる傾向となる。case 4 の場合は，負值 を取るパネルのうち，節点 15 を含むものが同じパタ一 ン $\left(\sigma_{T G}=0.0125 \mathrm{~cm}\right.$ を除く) で現れ，次いで節点 9 を 含むパネルに負值を示す部材が多くみられる。

\section{7. 結 語}

本論では，ランダムな部材長さ誤差を有する単層ラチ スドームに生じる形状初期不整を構造解析によって発生 させる方法が示された。解析に際して，ねじ込み接合さ れたドームを構成する部材要素は，部材両端で接合部の 緩みを考慮してモデル化されている。数值シミュレ一 ションによって求めた結果を統計処理して部材長さ誤差 $\Delta l$ の標準偏差と初期不整の統計量（平均值と標準偏差） との関連から発生形状不整（ここでは，鈶直変位）およ び，部材軸力を推定した。得られた結果を以下に要約し 本手法の妥当性および，今後の課題に言及する。

（1）ランダムな部材長さ誤差の標準偏差と部材伸びお よび初期鉛直変位の標準偏差は，各々線形関係にある。 また，接合部の緩みの影響は，すべての節点について鉛 直変位の分布へ一様に現れる。各サンプルごとに求めた 鉛直変位と部材長さ誤差との関係は緩みの種類に応じて 異なり，軸力特性のみに緩みがある場合が，最小勾配と なった。

（2）部材軸力の平均值と標準偏差は，接合部の緩みに よりかなり変動する。特に, 境界周辺の各部材では,ドー 厶内部の部材に比べて軸力の変動は，2-3 倍の大きさ となる。このことから，構成部材の断面設計には，境界 周辺部材に注意を払う必要があるといえる。

（3）形状初期不整の空間分布を分析するには，各単位 6 角形パネルに関する局所平均統計量と各節点に対する 鉛直変位の最大値と最小值が重要となる。すなわち緩み を全く考慮しない場合には，局所平均と標準偏差は，ラ ンダムな部材長さ誤差の標準偏差と比例関係にある。そ うでない場合には，最大值の変動は，形状初期不整量の ほほ $3 \sigma$ 値に等しい。以上より，各パネルを構成する部 材の軸力の変動特性を把握するには，構造全体にわたり パネル位置と節点位置および，パネルを構成する部材位 置による発生軸力と，鉛直相対変位そして鉛直変位の空 間分布との関係を調べることが重要と考えられる。この ことは，初期不整の推定において必要な項目であり，構 造特性, 力学特性を反映させた形状初期不整の発生の問 題に関係するということを想起させる。

本論で示した初期不整発生の方法とその推定手法につ
いて，実測值が不足している現状から具体的にその妥当 性を含めて議論することは，困難と思われる。しかしな がら, 本研究と同様の部材構成による実験報告 ${ }^{13)}$ と比較 して大略妥当なものと判断される。すなわち，同実験報 告は，かなり䈌密な部材製作と可能な限り接合部の緩み を許容しない組立てによるドームを対象とした，単一の 試験から各節点の初期不整の值を示している。したがっ て統計的な裏付けに基づくものではないが，同報告では 鉛直変位量が最大 $+3 \mathrm{~mm}$ (上方向) で最小 $\pm 0 \mathrm{~mm}$, 相 対鉛直変位量が最小で $-1 \mathrm{~mm}$, 最大 $+2 \mathrm{~mm}$ となってい る。これは, 本論で示した接合部に緩みを考慮しない場 合の最小部材長さ䛊差に対する解析結果の $2 \sigma$ 值の範囲 にある。

以上のことから, 発生した形状初期不整の分布の節点 位置ごとの対応と同時に, 発生軸力の分布の部材ごとの 対応関係を統合して, 初期不整の推定が可能になれば設 計に有用な資料を提供できると考える。すなわち, 架構 の設計時に不整発生のメカニズムを考虑して初期不整を 確率・統計的に推定するには，本論で述べたように形状 初期不整の空間分布と関連づけることが望まれる。その ためには，部材長さ誤差の他に，接合部の緩み特性およ びジョイントの取り付け角度誤差なよ゙も不規則量として 扱い個々の不整要因に対して, 初期不整の発生とその推 定の問題を検討し，さらに各々の要因の相互作用の影響 について構造形式と施工方法を踏まえた解析的な研究が 必要であろう。

\section{謝 辞}

本研究を進めるにあたり，数値解析ならびに図表作成 において豊橋技術科学大学大学院生 生村昌明氏に多大 な御協力を頂きました。ここに，深く謝意を表します。

\section{Appendix 発生部材長さ㛊差の検討}

ランダムな部材長さ誤差のシミュレーションの結果を検討す るとき厳密には統計的検定が必要と思われるが，例えば設定標 準偏差 $\sigma_{\tau G}$ に対して発生させた擬似乱数の標準偏差 $\sigma_{\Delta l}$ の最大値

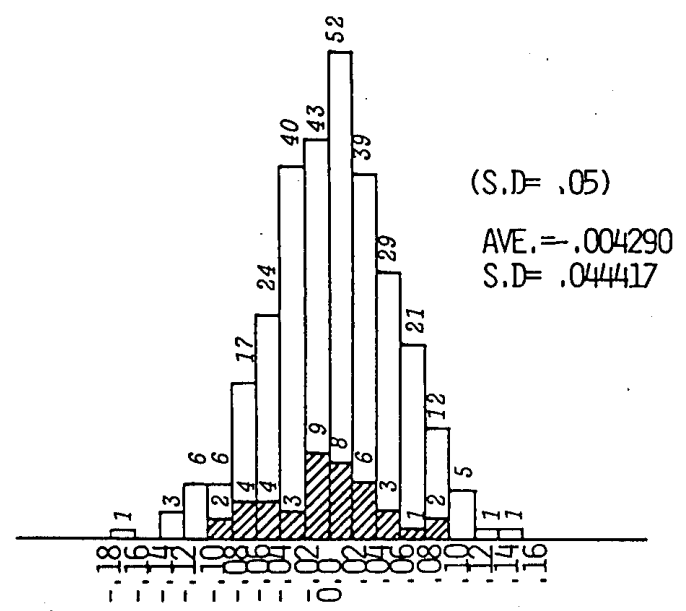

Fig. A-1 Sample histogram for seed No. 1 


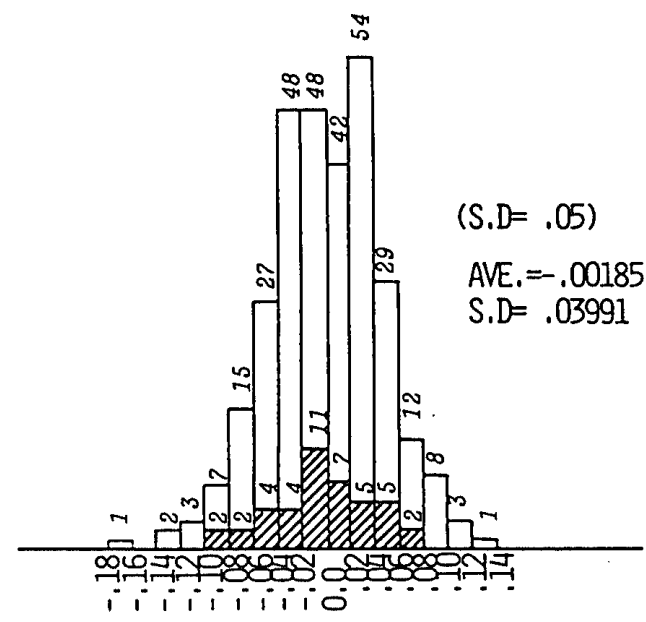

Fig. A-2 Sample histogram for seed No.2

と最小值は, 最小值側で設定値 $\sigma_{T \sigma}$ の $73 \%$, 最大值側で $93 \%$ となっている。発生サンプル群と抽出群（ハッチング）の頻度 分布の例が 2 種類のシードについて Fig. A-1，A-2 に示される。 同図は，各々平均値 0 で設定標準偏差 $\sigma_{T G}=0.05 \mathrm{~cm}$ の場合であ り図中にはカットオフの範囲が例示されている。なお，シード の違いによる統計量は，それぞれについてほぼ $10^{-3}$ から $10^{-4}$ 程度の差を示し，頻度分布も相対的にシフトしているが，サン プル群と抽出群とほぼ類似するといえよう。また，本論におい ては, Fig. A-1 の特性を示すシードが用いられている。

\section{参考文献}

1) Roorda, J. : Some Statistical Aspects of the Buckling of Imperfection Sensitive Structures, J. Mech, Phys. Solids, Vol.17, pp.111-136, 1969.

2）木村 勇ほか 6 名：鉄骨建方の精度管理一サンシャイン 60 に見る設計，製作，施工の一貫システム, JSSC, Vol. 15， No. 165, pp.1-10, 1979. 10.

3）高橋春蘭ほか 5 名：広がりのある建物の現場溶接と建方
精度の実際，建築技術，No.416，pp.87-98，1986.4.

4）椎名博美ほか 4 名：大型 PC 版工法の建方精度調查，日 本建筑学会大会学術講演梗概集（東北），pp.161-162, 1973. 10.

5）中西 宏, 波田凱夫：吊構造における施工䛊差上完成形 状について，日本建築学会大会学術講演梗概集 (中国), pp. 1011-1012, 1977. 10.

6）竹村勝之, 坂井藤一, 赤尾 宏: 鋼橋の施工精度に関す る確率論的考察, 上木学会論文集, 第 380 号, I -7, pp. 391-400, 1987.4.

7.) 川口 衛：構造計画上の諸問題，スペースフレーム（立 体格子構造) 設計・解析・施工 (昭和 57 年度科研総合 $\mathrm{B}$ 報告代表：日置興一郎)，pp. 14-25，1983.3.

8）石川浩一郎, 高島英幸, 加藤史郎：ピン接合三㑇形網目 状単層トラスドームの座屈荷重についての考察 (その2), 日本建築学会大会学術講演梗概集 (近畿) B, 構造 I, pp. 1289-1290, 1987. 10.

9）向山洋一, 武藤 至, 加藤史郎：単層トラスドームの形 状初期不整の推定, 日本建築学会大会学術講演梗概集（近: 畿) B，構造 I，pp. 1303-1304，1987. 10.

10）日本建築学会：鉄骨精度測定指針， 1986.

11）加藤史郎, 石川浩一郎：ピン接合単層ラチスドームの弾 性座屈性状の分析と座屈荷重の推定, 日本建筑学会構造: 系論文報告集，第 393 号，pp. 118-127，1988.11.

12）坂寿二, 日置興一郎：ねじ込み接合で組み立てた立体 トラスの座屈挙動, 日本建築学会論文報告集, 第 331 号, pp. 1-9, 1983.9.

13）生村昌明, 植木隆司, 向山洋一, 久保寺勲, 高島英行, 加藤史郎：単層ラチスドームの実大載荷実験及び弾塑性 座屈解析, 日本建築学会大会学術講演梗概集 (九州) B, 構造 I，pp. 1251-1252，1989. 10.

(1990 年 8 月 30 日原稿受理, 1991 年 2 月 26 日採用決定) 